\title{
Steatosis Pada Hepar dan Fruktosa Dosis Tinggi Pada Penelitian Fruktosa
}

\author{
Baharuddin ${ }^{1 *}$ \\ ${ }^{1}$ Fakultas Kedokteran, Universitas Surabaya, Surabaya-Indonesia \\ *corresponding author: baharuddin@staff.ubaya.ac.id
}

Abstract-Fructose is a natural ingredient that is widely used as a sweetener substitute for glucose. Effectiveness and efficiency are the main reason so many industries use fructose to be consumed. Dosage is based on the toxicity of fructose consumption is divided into: a low-dose, medium-dose and high dose. It said consumption of high doses when someone is $100 \mathrm{~g} /$ day or more. Many products it does not include the type and quantity of sugar fructose in food and beverage packaging and lack of knowledge lead to uncontrolled fructose consumption in developed countries. Consequences of uncontrolled doses can lead to liver disorder and others tissue. The liver is the org an forming fatty compounds as a homeostatic mechanism. Fructose is based on theoretical and experimental likely responsible for the formation of steatosis. In the organolepticinspection on the provision of high doses of fructose seen their fat droplets are large, which indicates steatosis. Nevertheless still needed histopathology for diagnosis. Additionally duration of fructose to animals try to be more prolonged (>2 months) to see the response to the homeostasis of the body fat is formed.

Keywords: steatosis, fruktosa, liver

\begin{abstract}
Abstrak-Fruktosa merupakan bahan alam yang digunakan secara luas sebagai pemanis pengganti glukosa. Efektivitas dan efisiensi menjadi alasan utama sehingga banyak industri menggunakan fruktosa untuk dikonsumsi. Dosis konsumsi fruktosa berdasarkan toksisitas dibagi menjadi: dosis rendah, dosis sedang dan dosis tinggi. Dikatakan dosis tinggi ketika konsumsi seseorang berada di 100gr/hari atau lebih. Tidak dicantumkannya jenis gula dan kuatitas fruktosa dalam bahan makanan dan minuman kemasan serta kurangnya pengetahuan menga kibatkan konsumsi fruktosa tidak terkontrol pada negara-negara maju. Konsekuensi dosis yang tidak terkontrol ini dapat mengakibatkan gangguan pada organ hati. Hati merupakan organ pembentuk senyawa lemak sebagai mekanisme homeostasis. Fruktosa berdasarkan teoritik dan eksperimental kemungkinan besar bertanggung jawab terhadap pembentukan steatosis. Pada pemeriksaan seca ra organoleptik pada pemberian fruktosa dosis tinggi terlihat adanya droplet lemak berukuran besaryang menandakan a da nya steatosis. Walaupun demikian masih sangat dibutuhkan pemeriksaan histopatologi untuk menegakkan diagnosa. Selain itu durasi pemberian fruktosa terhadap hewan coba harus lebih diperpanjang (>2 bulan) untuk melihat tanggapan homeostasis tubuh terhadap lemak yang terbentuk.
\end{abstract}

Kata kunci: steatosis, fruktosa, hati

\section{PENDAHULUAN}

Fruktosa

Fruktosa merupakan bahan alamiah yang banyak ditemukan dalam buah-buahan. Walaupun demikian beberapa spesies tanaman menganduk fruktosa pada batang. Selain di buah fruktosa juga banyak terkandung di dalam madu yang merupakan produk sistem pencernaan lebah. Senyawa fruktosa memiliki rumus molekul $\mathrm{C}_{6} \mathrm{H}_{12} \mathrm{O}_{6}$ yang seisomer dengan glukosa dan galaktosa. Fruktosa menjadi sangat terkenal ketika madu digunakan secara luas sebagai bahan pemanis yang kuat. Seiring berjalannya waktu produktiivitas madu mulai menurun akibat polusi yang mempengaruhi populasi lebah secara global. Para peneliti di berbagai negara pun berusaha keras mengembangkan berbagai inovasi untuk memperoleh fruktosa. Penelitian ini pun berhasil mereka mendapatkan fruktosa dari fermentasi jagung. Produk fruktosa dari jagung ini dikenal sebagai High Fructose Corn Syrup (HFCS). Gaya hidup masyarakat perkotaan yang bergerak ke konsumsi makanan dan minuman kemasan menjadi kekhawatiran global. Kekhawatiran ini terutama difokuskan pada anak-anak usia sekolah dan remaja yang tidak mengetahui dan menyadari total fruktosa yang dikonsumsi setiap harinya. Ditambah lagi saat ini berdasarkan observasi yang kami lakukan banyak produk makanan dan minuman yang tidak mencantumkan jenis gula yang mereka gunakan. Kalaupun dicantumkan biasanya tidak disertakan dengan kuantitas fruktosa yang dikandung produk tersebut. 


\section{Dosis Fruktosa}

Total fruktosa atau dosis yang dikonsumsi setiap hari memiliki efek terhadap kesehatan. Dosis fruktosa dalam beberapa penelitian disebutkan ada tiga yaitu: rendah, sedang dan tinggi. Dikatakan sebagai dosis tinggi ketika konsumsi berada pada $100 \mathrm{gr} / \mathrm{hari}$ atau lebih. Konsumsi fruktosa dibeberapa negara adalah bervariasi. Negara Amerika contohnya pada penelitian tahun 2000 memperlihatkan bahwa rata-rata 9\% dietary intake nya berasal dari fruktosa [1]. Kemungkinan besar kondisi tersebut juga terjadi Indonesia. Variasi ini dimungkinkan karena kultur budaya dan hasil alam setiap pula juga bervariasi. Namun demikian data mengenai detail fruktosa untuk negara Indonesia masih belum ada yang terpublikasi. Fruktosa melupakan molekul organik yang dapat dimetabolisme oleh tubuh. Semakin banyak fruktosa yang diserap oleh usus akan semakin banyak produk metabolisem jalur lain yang akan terbentuk. Menjadi unik dan sangat mengkhawatirkan ketika mengkonsumsi fruktosa secara berlebihan karena absorbsi fruktosa pada enterosit berlangsung secara pasif [2] tanpa ATP dan natrium independent.

\section{Absorbsi dan Metabolisme Fruktosa}

Mekanisme pada absorbsi fruktosa telah diketahui menggunakan Glucose Transporter 5 (GLUT5) pada brush border enterosit[3]dan tidak menggunakan natrium. Fruktosa yang berada di dalam darah ini kemudian akan diedarkan ke seluruh jaringan perifer termasuk sel hati.Penyerapan fruktosa oleh hati menggunakan GLUT 2. Absorbsi fruktosa oleh sel-sel hepatosit dan sel lain tidak dipengaruhi oleh insulin [4], [5]. Dalam sel hati fruktosa selanjutnya difosforilasi oleh fruktokinase menjadi fruktosa 1-fosfat (F1P). Keunikan dalam jalur ini bahwa enzim fosfofruktokinase tidak kompatible dengan F1P sehingga F1P tidak dapat dimetabolisme. Fosfofruktokinase hanya dapat mengkatalisis fruktosa 6 fosfat (F6P). Akibatnya aldolase mengambil peran untuk memetabolismeF1P ini menjadi gliseraldehida 3 fosfat (G3P) dan dehidroksi aseton fosfat (DAP) [6]. Mekanisme ini memperlihatkan adanaya penghilangan atau pemendekan jalur yang dikenal dengan by pass fructose. Fruktosa berdasarkan analisis diubah menjadi tiga molekul utama yaitu: laktat, glukosa dan glikogen [7].

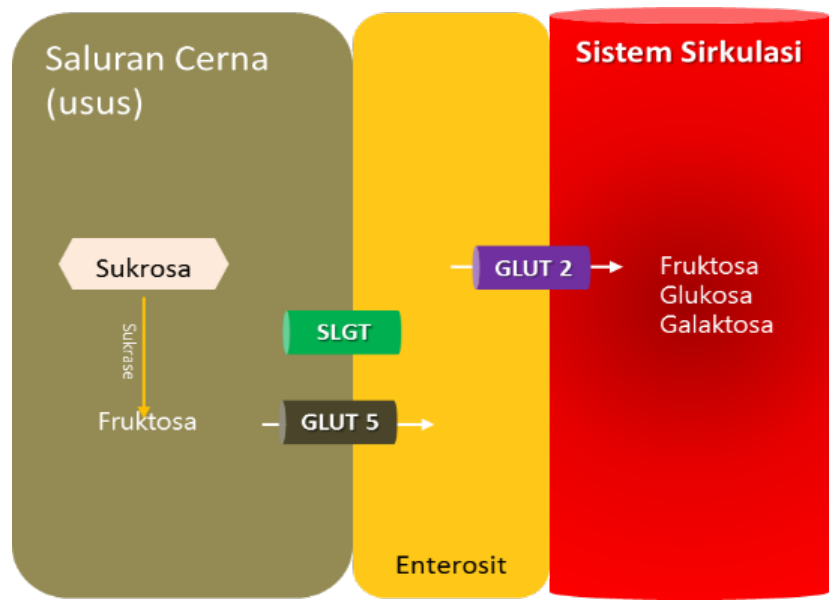

Gambar 1. Skema proses penyerapan fruktosa yang berlangsung di usus halus.

\section{Steatosis}

Steatosis atau perlemakan hati merupakan kondisi kronis yang terjadi pada hepar dengan sign organoleptik berupa droplet lemak berwarna putih atau sekurang-kurangnya $5 \%$ lemak pada hepatosit [8]. Droplet lemak yang terbentuk tersusun atas trigliserida (TG) yang dibungkus oleh fosfolipid monolayer [9]. Molekul TG ini dapat terakumulasi dalam jumlah yang signifikan [10]. Karena TG ini terbungkus oleh fosfolipid, maka kondisi steatosis sering juga 
dihubungkan dengan fosfolipodosis [8]. Penyebab terjadinya steatosis adalah beragam pada setiap orang.

\section{Efek Fruktosa Dosis Tinggi pada Hepar}

Fruktosa memiliki efek terhadap hepar yang diperlihatkan dengan kenaikan paramameter biokimia pada berbagai penelitian. Berdasarkan penelitian yang telah kami lakukan pada grup kontrol dan 2 grup dosis fruktosa (rendah dan tinggi) secara statistik memperlihatkan perbedaan yang signifikan $(P<0,05)$ untuk kadar glukosa. Uji organoleptik pada organ hepar memperlihatkan droplet lemak tunggal yang berukuran besar dan kecil pada Gambar 2.

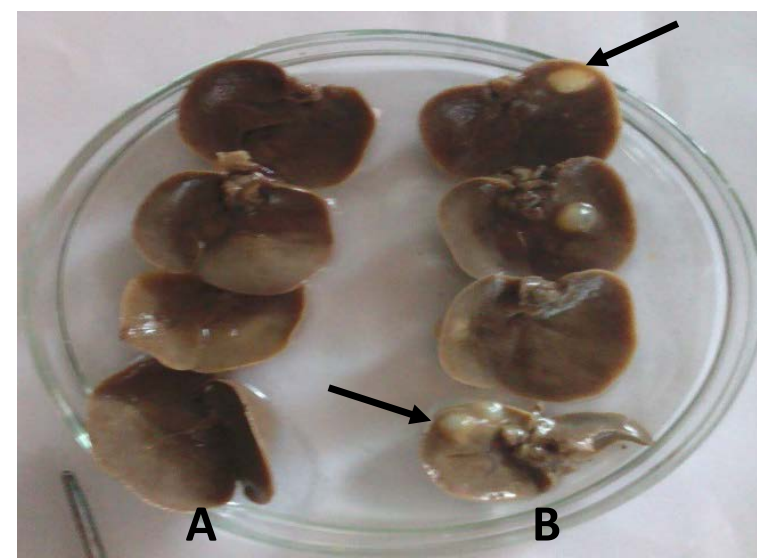

Gambar 2. Organ hepar tikus (rattus norvegicus). A) Pemberian fruktosa dosis dosis $450 \mathrm{mg} / 150$ grBB tikus. B) pemberian fruktosa dosis $1350 \mathrm{mg} / 150 \mathrm{grBB}$ tikus. droplet lemak ditunjukkan dengan tanda panah hitam. organ tikus merupakan representatif dari kelompok.

Droplet lemak pada hepar merupakan hasil deposit metabolisme baik yang berasal dari karbohidrat atau dari lemak yang terkandung dalam makanan. Analisis ini didasari oleh fungsi organ hepar sebagai organ deposit untuk menjaga kondisi energi tubuh tubuh selalu dalam kondisi homeostasis.

\section{SIMPULAN}

Fruktosa dosis tinggi memberikan risiko yang buruk terhadap kesehatan. Fruktosa secara teoritik dan eksperimental kemungkinan memiliki hubungan dan bertanggungjawab terhadap steatosispada hati. Oleh karena itu, perlu untuk mengatur konsumsi fruktosa baik dari makanan dan minuman.

Melihat steatosis adalah sebuah kondisi kronis maka sangat perlu dilakukan penelitian lanjutan dengan durasi waktu yang lebih panjang ( $>2$ bulan). Selain itu yang lebih penting lagi dalam penelitian lanjutan nantinya harus dicantumkan pemeriksaan histopatologi untuk menegakkan diagnosa.

\section{PUSTAKA ACUAN}

1. J. P. Bantle, S. K. Raatz, W. Thomas, and A. Georgopoulos, "Effects of dietary fructose on plasma lipids in healthy subjects 1-3," Am. J. Clin. Nutr., vol. 72, no. 5, pp. 1128-1134, 2000.

2. J. K. Huttunen, "Fructose in medicine," Postgrad. Med. J., vol. 47, no. October, pp. 654659, 1971.

3. J. Baynes and M. H. Dominiczak, Medical Biochemistry: With STUDENTCONSULTOnline Access, 4e. 2015.

4. E. M. Agency, "Information in the package leaflet for fructose and sorbitol in the context of the revision of the guideline on 'Excipients in the label and package leaflet of medicinal 
products for human use' ( CPMP / 463 / 00 Rev . 1)," 2016.

5. R. R. Henry, A. Crapo, and A. W. Thorburn, “Current Issues in Fructose," pp. 21-39, 1991.

6. D. M. Klurfeld, "Fructose: Sources, Metabolism, and Health," in Encyclopedia of Food and Health, Elsevier, 2016, pp. 125-129.

7. P. A. Mayes, "Intermediary metabolism of fructose," Am J Clin Nutr, vol. 58, p. 754S-65S, 1993.

8. J. Willebrords, I. Veloso, A. Pereira, M. Maes, S. C. Yanguas, I. Colle, B. Van Den Bossche, T. Cristina, C. P. Oliveira, W. Andraus, V. Avancini, F. Alves, and B. Cogliati, "Strategies, models and biomarkers in experimental non- alcoholic fatty liver disease research," pp. 106-125, 2016.

9. K. Tauchi-Sato, S. Ozeki, T. Houjou, R. Taguchi, and T. Fujimoto, "The surface of lipid droplets is a phospholipid monolayer with a unique fatty acid composition," J. Biol. Chem., vol. 277, no. 46, pp. 44507-44512, 2002.

10. A. Penno, G. Hackenbroich, and C. Thiele, "Phospholipids and lipid droplets," Biochim. Biophys. Acta-Mol. Cell Biol. Lipids, vol. 1831, no. 3, pp. 589-594, 2013. 